\title{
THE DEVELOPMENT OF COW EGGS IN THE RABBIT OVIDUCT AND THEIR VIABILITY AFTER RE-TRANSFER TO HEIFERS
}

\author{
R. A. S. LAWSON, ${ }^{*}$ L. E. A. ROWSON AND C. E. ADAMS \\ ARC Unit of Reproductive Physiology and Biochemistry, 307 Huntingdon Road, Cambridge
}

(Received 28th August 1971, accepted 16th September 1971)

Sheep eggs continue to cleave and retain their viability following transfer to the rabbit oviduct irrespective of the endocrine status of the recipient (Averill, Adams \& Rowson, 1955; Hunter, Bishop, Adams \& Rowson, 1962; Adams, Moor \& Rowson, 1968). In the case of cow eggs, Hafez \& Sugie (1963) concluded that the environment provided in the genital tract of the pseudopregnant rabbit was unsuitable to support their development. Subsequently, however, Adams et al. (1968) found that a high proportion of cow morulae could develop into blastocysts in the oviducts of follicular-phase rabbits whilst Sreenan, Scanlon \& Gordon (1968) reported that about half of the transferred eggs underwent some development in pseudopregnant rabbits.

In none of these studies, however, was the viability of cow eggs tested by retransferring them from the rabbit back to cattle. This was done in the present study.

Using the technique described by Rowson, Moor \& Lawson (1969), a total of forty-eight fertilized cow eggs was recovered, using TCM 199 as the flushing medium, from seven gonadotrophin-treated heifers, which had been in heat 2 to 4 days previously. Immediately after recovery, the eggs were examined microscopically $(x 100)$ to ascertain their stage of development. They were then transferred to the oviducts of untreated, adult rabbits which had been caged individually for at least 3 weeks. A single cotton ligature was placed on the tubal side of the uterotubal junction to prevent the eggs entering the rabbit's uterus. Recipient rabbits were killed after 2, 3 or 4 days to permit recovery of the cow eggs. For this purpose, the oviducts were severed from the uterus immediately distal to the ligature and, after trimming away the fatty and connective tissue, were flushed with $2 \mathrm{ml}$ TCM 199 into collecting dishes. Details of this part of the experiment are given in Table 1. Eggs transferred at the one-cell stage were considered likely to be fertilized since they contained spermatozoa in their zonae pellucidae and in some eggs two polar bodies were visible. Of the forty-eight eggs transferred, forty-one $(85.4 \%)$ were recovered and, of these, thirty-four appeared normal. The remaining seven eggs $(17 \cdot 1 \%)$ had either failed to develop or had fragmented. All of the one-cell eggs had developed into morulae of eight to sixteen cells and the majority of the two and

\footnotetext{
* Present address: S. S. Cameron Laboratories, Department of Agriculture, State Research Farm, Werribee, Victoria, Australia.
} 
four cell eggs had reached the sixteen cell stage at recovery 3 days after transfer. Eggs transferred with eight cells developed to late morulae or blastocysts after 2 or 4 days, respectively.

TABLE 1

THE STAGE OF DEVELOPMENT ATTAINED BY COW EGGS IN RELATION TO THEIR DEVELOPMENT AT THE TIME OF RECOVERY FROM DONOR HEIFERS AND THE TIME SPENT IN THE RABBIT'S OVIDUCT

\begin{tabular}{|c|c|c|c|c|c|c|c|c|}
\hline \multirow{2}{*}{$\begin{array}{l}\text { Days in } \\
\text { rabbit } \\
\text { oviduct }\end{array}$} & \multirow{2}{*}{$\begin{array}{l}\text { Stage of } \\
\text { development } \\
\text { at transfer }\end{array}$} & \multirow{2}{*}{$\begin{array}{l}\text { No. of eggs } \\
\text { transferred }\end{array}$} & \multirow{2}{*}{$\begin{array}{l}\text { No. eggs } \\
\text { recovered }\end{array}$} & \multicolumn{5}{|c|}{ Siage of development at recovery } \\
\hline & & & & Degenerate & Eight-cell & Sixteen-cell & Morulae & Blastocysts \\
\hline $\begin{array}{l}2 \\
3 \\
3\end{array}$ & $\begin{array}{l}\text { Eight-cell } \\
\text { One-cell } \\
\text { Two- and } \\
\text { four-cell }\end{array}$ & $\begin{array}{r}6 \\
6 \\
17\end{array}$ & $\begin{array}{r}6 \\
6 \\
14\end{array}$ & 3 & $\begin{array}{l}2 \\
2\end{array}$ & $\begin{array}{l}4 \\
9\end{array}$ & 6 & \\
\hline $\begin{array}{l}3 \\
4\end{array}$ & $\begin{array}{l}\text { Eight-cell } \\
\text { Eight-cell }\end{array}$ & $\begin{array}{r}2 \\
17\end{array}$ & $\begin{array}{r}2 \\
13\end{array}$ & $\begin{array}{l}1 \\
3\end{array}$ & & & $\begin{array}{l}1 \\
5\end{array}$ & 5 \\
\hline Total & & 48 & 41 & 7 & & 34 & & \\
\hline
\end{tabular}

TABLE 2

THE RESULTS OF RETRANSFERRING COW EGGS TO REGIPIENT HEIFERS AFTER SPENDING 3 OR 4 DAYS IN THE RABBIT OVIDUGT

\begin{tabular}{|c|c|c|c|c|c|c|}
\hline $\begin{array}{l}\text { Recipient } \\
\text { heifer }\end{array}$ & $\begin{array}{l}\text { Stage of } \\
\text { development } \\
\text { of eggs } \\
\text { at transfer }\end{array}$ & $\begin{array}{c}\text { Days in } \\
\text { rabbit } \\
\text { oviduct }\end{array}$ & $\begin{array}{c}\text { Stage } \\
\text { of development } \\
\text { and no. of eggs } \\
\text { retransferred }\end{array}$ & $\begin{array}{c}\text { Synchroniza- } \\
\text { tion } \\
(\text { days })^{*}\end{array}$ & $\begin{array}{l}\text { Postoperative } \\
\text { cycle length } \\
\text { (days) }\end{array}$ & $\begin{array}{c}\text { Calves } \\
\text { born }\end{array}$ \\
\hline $\begin{array}{l}1 \\
2 \\
3 \\
4\end{array}$ & $\begin{array}{l}\text { Two and four-cell } \\
\text { Two and four-cell } \\
\text { Two and four-cell } \\
\text { Two and four-cell }\end{array}$ & $\begin{array}{l}3 \\
3 \\
3 \\
3\end{array}$ & $\begin{array}{l}\text { Sixteen-cell (2) } \\
\text { Sixteen-cell (2) } \\
\text { Sixteen-cell (2) } \\
\text { Eight-cell (1), }\end{array}$ & $\begin{array}{l}2 \\
2 \\
2 \\
2\end{array}$ & $\begin{array}{l}20 \\
21 \\
17 \\
23\end{array}$ & $\begin{array}{l}\text { E } \\
\text { E }\end{array}$ \\
\hline $\begin{array}{l}5 \\
6 \\
7\end{array}$ & $\begin{array}{l}\text { One-cell } \\
\text { One-cell } \\
\text { One-cell }\end{array}$ & $\begin{array}{l}3 \\
3 \\
3\end{array}$ & $\begin{array}{l}\text { sixteen-cell (1) } \\
\text { Eight-cell (2) } \\
\text { Sixteen-cell (2) } \\
\text { Eight-cell (1), } \\
\text { sixteen-cell (1) }\end{array}$ & $\begin{array}{l}0 \\
0 \\
1\end{array}$ & $\frac{22}{-}$ & $\begin{array}{l}\overline{2} \\
2\end{array}$ \\
\hline $\begin{array}{r}8 \\
9 \\
10 \\
11 \\
12\end{array}$ & $\begin{array}{l}\text { Eight-cell } \\
\text { Eight-cell } \\
\text { Eight-cell } \\
\text { Eight-cell } \\
\text { Eight-cell }\end{array}$ & $\begin{array}{l}3 \\
4 \\
4 \\
4 \\
4\end{array}$ & $\begin{array}{l}\text { Morula (1) } \\
\text { Morulae (2) } \\
\text { Morulae (2) } \\
\text { Blastocyst (1) } \\
\text { Morula (1), } \\
\text { blastocyst (1) }\end{array}$ & $\begin{array}{l}1 \\
0 \\
1 \\
0 \\
0\end{array}$ & $\frac{-}{\overline{18}}$ & $\begin{array}{l}1 \\
2 \\
3 \dagger \\
-1\end{array}$ \\
\hline
\end{tabular}

* No. of days after the onset of oestrus in the donor that recipient heifers were in oestrus.

$\uparrow$ Probably an extra egg transferred unintentionally.

Whenever suitably synchronized recipient heifers were available, eggs that were considered normal were retransferred surgically to test their viability. When two eggs were transferred, one was placed in each uterine horn, whilst single eggs were placed in the horn adjacent to the ovary that had ovulated. Altogether twenty-two eggs which had spent 3 or 4 days in the rabbit oviduct were transferred to twelve heifers. Details of these transfers are given in Table 2. 
Four of the recipients (Nos. 1 to 4), which failed to become pregnant had been in oestrus 2 days later than their respective donors. As yet unpublished work (Rowson, Lawson, Moor \& Baker) indicates that conception rates following surgical egg transfer decline from $91 \%$ when the time of the onset of oestrus in the donor and recipient is exactly synchronized to 30 to $40 \%$ if they differ by 2 days.

Of the remaining eight recipients in which oestrus occurred on the same day as, or on the day following, oestrus in the respective donor heifers, six became pregnant. One set of triplets, three twin and two singleton calves were born. In the case of the triplets, two bulls and a heifer, it is presumed that a third egg was transferred unintentionally; the bull calves were not monozygous. Thus, excluding the less well synchronized donor-recipient combinations, the transfer of fifteen eggs yielded eleven calves; a survival rate of $73 \%$. It is concluded, therefore, that one- to eight-cell cow eggs can continue to develop normally and remain viable after spending at least 3 to 4 days in the rabbit oviduct. Cow eggs have not so far been cultured in vitro beyond the twenty-fourcell stage (Thibault, 1970).

The proportion of cow eggs in the present experiments that continued to develop in the rabbit is comparable with that reported by Adams et al. (1968) and much superior to that reported by Hafez \& Sugie (1963), who found that only five out of sixty-nine eggs continued to cleave in pseudopregnant rabbits. The use of homologous serum as the transfer medium by Hafez \& Sugie may explain their lack of success. Rowson et al. (1969) reported that homologous serum is deleterious to the survival of cow eggs. Serum has also proved relatively unsatisfactory, as judged on the basis of continued cleavage, when cow eggs were transferred to the oviducts of pseudopregnant rabbits (unpublished data).

The present experiments indicate that it should be possible to transport cow eggs over long distances and, following their retransfer to suitable recipients, obtain viable offspring, thus providing a cheap means of exporting cattle. A comparable sequence of events has already been demonstrated with sheep (Hunter et al., 1962). In the absence of satisfactory procedures for culturing cow eggs in vitro, the technique is also being used to assess egg viability in experiments concerned with fertilization in vitro and low temperature storage.

\section{REFERENCES}

Adams, G. E., Moor, R. M. \& Rowson, L. E. A. (1968) Survival of cow and sheep eggs in the rabbit oviduct. Proc. 6th Int. Cong. Anim. Reprod. A. I., Paris, 1, 573.

Averill, R. L. W., Adams, C. E. \& Rowson, L. E. A. (1955) Transfer of mammalian ova between species. Nature, Lond. 176, 167.

Hafez, E. S. E. \& Sugre, T. (1963) Reciprocal transfer of cattle and rabbit embryos. F. Anim. Sci. 22, 30.

Hunter, G. L., Bishop, G. P., Adams, G. E. \& Rowson, L. E. (1962) Successful long-distance aerial transport of fertilized sheep ova. 7. Reprod. Fert. 3, 33.

Rowson, L. E. A., Moor, R. M. \& LAwson, R. A. S. (1969) Fertility following egg transfer in the cow: effect of method, medium and synchronization of oestrus. F. Reprod. Fert. 18, 517.

Sreenan, J., Scanlon, P. \& Gordon, I. (1968) Culture of fertilized cattle eggs. F. agric. Sci., Camb. 70, 183.

Thibault, G. (1970) La culture in vitro de l'œuf de vache. Annls Biol. anim. Biochem. Biophys. 10, 141. 